\title{
Fortification of wheat flour with iron: development of a quality assurance system
}

Sanath P.Mendis ${ }^{1}$

The Ceylon Journal of Medical Science 1999; 42: 43-53

\section{Introduction}

Iron Deficiency Anaemia (IDA) has been identified as a problem of public health significance in Sri Lanka (1). As a part of its programme to combat iron deficiency in the population, the Government of Sri Lanka (GOSL) has conducted a series of trials and studies on the feasibility of fortification of wheat flour with iron. These studies have been carried out under the iron fortification of wheat flour project which began in 1994 jointly sponsored by the GOSL $(2,3,4)$ (Ministry of Finance, Planning, Ethnic Affairs and National Integration) and USAID.

The GOSL under the project is currently implementing an efficacy trial to demonstrate that fortification of wheat flour with iron could reduce the prevalence of iron deficiency anaemia in the population. There are favourable considerations and national interest on fortification of wheat flour with iron. With this prospect it is important to develop a proposal for a quality assurance system for iron-fortified wheat flour which could be implemented once a national programme for fortification of wheat flour with iron gets under way.

This is a summary of observations and recommendations made in the report on the development of a quality assurance system for fortification of wheat flour with iron. The full report will be published by the Ministry.

\section{Objectives and Scope}

This study was undertaken as a part of the "Iron Fortification of Wheat Flour" project with the broad objective of developing a quality assurance system for application in the production of wheat flour fortified with iron for consumption by the Sri Lankan population. Specific objectives are;

- Identification of quality aspects and criteria for ingredients and processes involved.

- Identification of control points in the processing, packaging and distribution, and to establish control and monitoring procedures at each control point.

- Develop a recording and verification system for the quality assurance and quality control activities.

The above aspects have been addressed with specific reference to the activities and processes in: volved in the fortification of wheat flour with iron. The quality assurance activities required to secure the desired quality of wheat flour in the milling process such as cleaning of grain, blending, conditioning of grain for milling, sieving sifting operations have not been specifically addressed. The quality assurance practices in place at present are considered adequate to achieve the required quality level as specified in the National Standards.

In this report the term "quality assurance" refers to all those planned and systematic actions necessary to provide adequate confidence that a product or service will satisfy given requirements for quality.

\section{Decision on fortificant and fortification level}

Under phase II of the project studies have been carried out to evaluate effects on products made from wheat flour fortified with different

\section{Deputy Director General, Sri Lanka Standards Institution, Dharmapala Mawatha, Colombo 7.}


fortificants. The following fortificants have been included in the study;

\section{Electrolytic Iron \\ Reduced Iron \\ $\mathrm{Na}$ Fe EDTA \\ Ferrous fumarate \\ Ferrous sulphate}

Through studies carried out in Phase I of the project it has been recommended that both fortificants be tested at $66 \mathrm{mg} / \mathrm{kg}(3,4)$. Final recommendations could be made only after the conclusion of efficacy trials now being carried out under Phase II of the project.

\section{Present status in production of wheat flour}

Prima Ceylon Ltd. mills and supplies the full national requirement of wheat flour. The average daily production of wheat flour at Prima mill is $2500 \mathrm{M}$. Ton per day. Production facility consist of 5 milling lines producing $500 \mathrm{MT}$ per day on each line.

Quality control activities in operation at present are considered adequate for production of wheat flour meeting the specified standards. The laboratory is equipped to carry out quality tests for wheat grain and wheat flour. The tests carried out include protein, ash, moisture, amylase activity, gluten, other physical, chemical and rheological properties affecting baking quality of flour.

Quality control activities in operation at present includes the following;

(a) Receiving of Grain -

\begin{tabular}{l|l} 
protein & $\begin{array}{l}\text { samples are collected } \\
\text { every 15 minutes dur- } \\
\text { ash }\end{array}$ \\
moisture & $\begin{array}{l}\text { and composing of grain } \\
\text { are tested 4 hourly. }\end{array}$
\end{tabular}

(b) Blending of Grain -

Grain classified as hard/semi-hard/soft, based on protein content and protein quality, are blended to give the required protein content. Grain is tempered to aid in the milling process and achieve the required moisture content.

(c) Milled Flour moisture

ash

protein

gluten

extensograph

(physical and

four hourly samples taken from each of five lines analysed separately.

A ribbon blender of $80 \mathrm{~kg}$ capacity (supplied under the project) is available for pre-mixing of fortificant. Metering equipment for feeding dry material to the line is available on production lines (05) for additives. Additional metering equipment for addition of iron has been supplied under the project for one line. This equipment is currently used in the production of iron fortified wheat flour for the efficacy trials.

\section{Process for fortification of wheat flour with iron}

Flow chart indicating the process (proposed) for fortification of wheat flour with iron is given in Schedule 1 . The production facility at Prima Flour mill consists of five(5) milling lines with each line producing $500 \mathrm{MT}$ per day with a total output of $2500 \mathrm{MT}$ per day.

The basic process for fortification of wheat flour with iron is as follows; The fortificant is first mixed with wheat flour in a ribbon blender in the ratio $1: 1$. This is to dilute the fortificant to facilitate the process of addition to the wheat flour bulk. The addition of pre-mix is direct to the wheat flour conveyor using volumetric feeders of suitable capacity. The product flow on lines are reported to be stable and uniform. Therefore, the metering of pre-mix on to each of the five milling lines could be adjusted to a constant rate to give the desired rate of addition. Further mixing takes place as the product goes through several stages of conveyors and mixers. 
The required rate of addition of pre-mix (1:1) is $130 \mathrm{~g}$ per MT of flour produced to give an effective level of $65 \mathrm{mg}$ iron $/ \mathrm{kg}$ flour. On this basis the daily requirment of pre-mix for 2500 MT of wheat flour is $325 \mathrm{~kg}$. The ribbon blender of $80 \mathrm{~kg}$ capacity available at present is adequate for the production of pre-mix required for the total production of flour for all five lines. However, it is proposed that an additional Ribbon blender be provided to accomodate heavy work load and possible break downs.

Metering equipment for the addition of iron premix is now available only on one line (supplied under the project). This volumetric feeder is of adequate capacity and capability to achieve the required rate of feeding. It would therefore be necessary to provide 4 volumetric feeders of similar capacity for the 4 lines which are not equipped with feeders.

\section{Quality issues in the fortification programme}

Quality issues or factors relating to quality and safety which need to be addressed in a fortification programme are highlighted in sections 1 to 6 below. For each of these aspects, possible control measures and mechanics for application of these measures are given in section 7 and presented in the form of a quality assurance plan (Schedule 2).

1. Quality and purity of fortificant - The fortificant used should conform to specifications covering quality and purity requirements. These would cover nature of material, particle size, iron content and associated impurities. Possible contamination arising from damage to containers during transit and storage should be considered and steps taken to avoid use of such material.

2. Quality of flour - The process control procedures presently in place for the milling process is considered adequate to meet the desired quality levels of wheat flour as specified in standards and technical regulations. The moisture content of wheat flour used in forti- fication is a critical parameter. The moisture content of wheat flour produced by Prima Ceylon Ltd. is in the range of 13.2 - 13.7 percent. Process control methods adopted at present are adequate to ensure conformity to these limits.

3. Production of premix - Fortificant is diluted by mixing with wheat flour in the ratio of 1:1. It is necessary to ensure that correct amounts of fortificant and wheat flour are mixed. The premixing is done in a ribbon blender. The desirable mixing time in the ribbon blender has been established as $3-4$ minutes. Studies carried out in the factory have shown that over-mixing tends to segregate the material, based on particle size. Therefore it would be necessary to follow the same mixing conditions (which are now considered optimum) to ensure consistency.

Note: a separate study would be required to establish the optimum mixing conditions.

4. Labelling and Storage of premix - It is necessary to store premix in properly labelled and identifiable containers or packages until these are used in the production line and added on to the bulk of wheat flour. The purpose of labelling is to facilitate the proper identification of the pre-mix material and to avoid any possibility of mix up with any other similar packages and material.

5. Addition of fortificant to wheat flour bulk - It would be necessary to ensure that fortificant is added at the correct rate/quantities and that homogeneous distribution of the fortificant in wheat flour bulk is achieved.

6. Storage of wheat flour and distribution - It is necessary to ensure that iron fortified flour is consumed within a targeted period of three months (maximum) since it has been shown that iron fortification reduces the shelf life of wheat flour. The present distribution system is such that the flour reaches the retail points within six weeks and are consumed within three months. 


\section{Quality assurance plan}

Based on the quality issues discussed in sections 1 to 6 (above) the control points at which the quality parameters could be controlled have been identified. The following have been identified for each control point (CP) and presented as a Quality Assurance Plan in Schedule 2.

- Process step/Control point

- Safety/Quality aspect (issues addressed)

- Control preventive measure

- Control limit

- Monitoring procedure

- Frequency

- Responsibility

- Records

The following aspects have to be noted in case of the relevant control points (Reference Schedule 2);

\section{CP1(a)-Analytical Reports and Certificates of} Conformity:-

Analytical reports and cetificates of conformity should be provided by the supplier with each batch. This should be made a condition of the tender and contract for supply of fortificant.

CP1(b)-Analysis of samples (raw material) on receipt-

It is envisaged that the supplies of fortificants will be received once in three months. It is recommended that each batch of supply be sampled and analysed. If the analytical reports are consistent with the reports provided by the supplier for five consecutive batches, sufficient reliability could be placed on the supplier's certificates and test reports. If the frequency of supplies is less 'than three months and the supplier's certificates and reports are reliable, frequency of testing could be reduced to 1 in 3 batches depending on frequency of supply. However sampling testing should be carried out at least once in three months.

CP1(d)-Storage of fortificant-

If the period of storage exceeds 3 months, the fortificant should he examined and analysed before use.

Note: Manufacturer's specifications indicate one year shelf life under dry conditions at ambient temperature.

CP3(a)-Labelling of pre-mix packages-

It is recommended that the pre-mix be packed in standard quantities and properly labelled to avoid any risk of mistaken identity.

CP3(b)-Storage of pre-mix-

This would be required, based on the practical production schedules adopted for pre-mix. Since studies on stability of premix has not been carried out, it is recommended that storage time be restricted to seven days. At the rate of consumption of $325 \mathrm{~kg}$ per day of pre-mix, the maximum bulked quantity should not exceed 2400 $\mathrm{kg}$ (7 days requirement).

$\mathrm{CP} 4$ (a)-Identification of pre-mix packages before addition-

This control activity is a preventive measure for any possible mix-up of packages of pre-mix and prevent use of pre-mix stored for periods beyond the specified limit. The daily requirement of pre-mix would be approx. $325 \mathrm{~kg}$ for $2500 \mathrm{MT}$ of flour.

CP4(b)-Quantity of pre-mix added-

It is desirable that the pre-mix package is of standard quantity which can be added at once to the hopper at feeder point. It will then be possible to record the quantity added with time of addition. This 
infomation would he used for the control activity at $\mathrm{CP} 4(\mathrm{~d})$, where daily records would be scrutinized.

\section{CP4(c)-Visual checks on the feeder}

Volumetric feeders are used. The correct feeding rate need to be worked out with tolerances to give a feeding rate of $130 \pm$ $5 \mathrm{~g}$ of pre-mix per 1MT of wheat flour. The meter readings should be checked regularly by line operators.

Note: It is also necessary to have an automated connection where the feeder would stop immediately if there is a stoppage in the line.

CP5(a)-Analysis of finished product for iron content-

This analysis should be carried out daily in-house. Daily samples of flour are analysed in the in-house laboratoty at Prima Ltd. Therefore, Fe determination should be carried out once a day on the samples collected.

CP6(a)(b)-Analysis of finished product for iron content-(by Food Department.)

This is part of the monitoring procedure to check that the fortification programme is functioning properly and adequately, and is supplementary to the verification procedure given in section 8 below. It is the responsibility of the $Q C$ unit of the Food Department to collect samples and arrange for testing. This would be done on contract in an accredited testing laboratory. Separate budgetory provision should be made to meet the cost of this testing. This should be combined with other QC tests carried out at present.

Note: Sampling techniques and methods given in SLS 144 to be used in collecting wheat flour samples for analysis.

\section{Verification procedures}

Verification procedures form an integral part of a Quality Assurance Plan. Verification activities should be carried out on a planned basis according to a scheduled programme. The following aspects should be covered in a verification process:

The first aspect of verification should be, to ensure that the QA plan at the mill is functioning effectively. A properly functioning QA plan requires little end product sampling and testing since appropriate safeguards for assuring quality are built into the process. This part of the verification process should involve the verification that the QA plan is correctly followed at different levels and the review of records at each $\mathrm{CP}$ as indicated in the QA plan. This verification of records at CP's should be carried out by internal staff (internal audits) at least once in three months. Records of such internal audits should be maintained for verification.

The second aspect is the performance of an external audit to verify that the QA plan is implemented in a proper manner. It is recommended that a surveillance audit of the QA system be carried out once in six months by a team of auditors nominated by GOSL (MFPEANI).

In addition to such verification procedure, independent monitoring and surveillance through testing of final product is recommended. These activities should be carried out as indicated under CP 6 in the QA plan. It is the responsibility of the QC unit of The Food Department to arrange for these tests. Adequate funds should be made available for this purpose.

Note: Specifications for fortificants and Methods of analysis; Testing facilities at flour mill of Prima Ceylon Ltd.; Cost of implementing the quality assurance plan, included in the report has not been included in this summary. 


\section{PROCESS FLOW CHART FOR IRON FORTIFICATION OF WHEAT FLOUR}

SCHEDULE 1

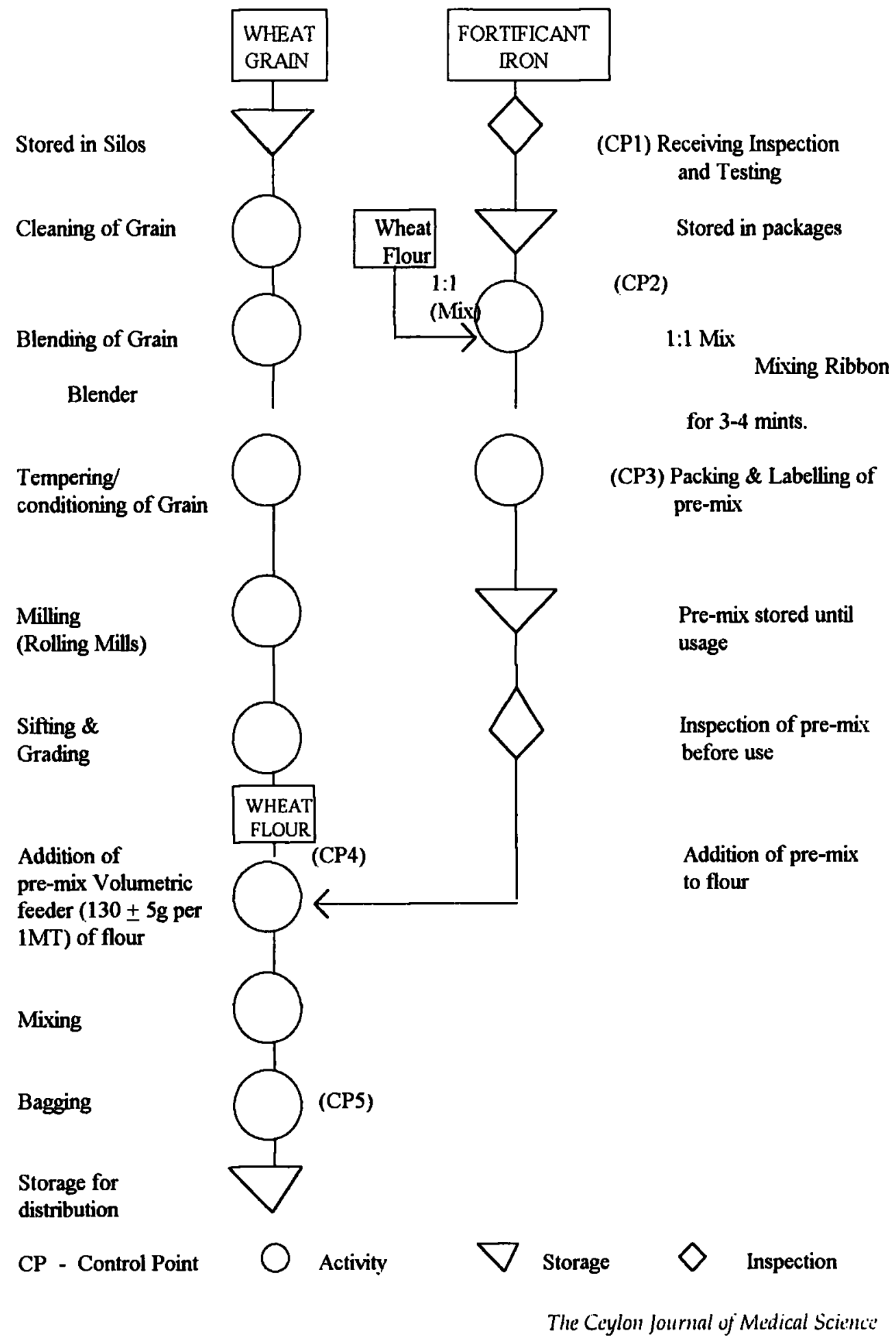


QUALITY ASSURANCE PLAN

\begin{tabular}{|c|c|c|c|c|c|c|c|}
\hline $\begin{array}{l}\text { PROCESS } \\
\text { STEPI } \\
\text { CONIROL } \\
\text { POINT }\end{array}$ & $\begin{array}{c}\text { SAFETY/QUALITY } \\
\text { ASPECT(ISSUE) } \\
\text { ADDRESSED) }\end{array}$ & $\begin{array}{l}\text { CONTROL } \\
\text { PREVENTTVE } \\
\text { MEASURE }\end{array}$ & CONTROL LMMT & $\begin{array}{l}\text { MONITORING } \\
\text { PROCEDURE }\end{array}$ & FREQUENCY & RESPONSIBILITY & RECORDS \\
\hline $\begin{array}{l}\text { RECEIVING } \\
\text { FORTIFICANT }\end{array}$ & $\begin{array}{l}\text { PURITYQUALITYOF } \\
\text { FORTIFICANT } \\
\\
\text { - } \text { Fe content } \\
\text { - } \text { Particle size } \\
\text { Impurities } \\
\text { - Ash } \\
\text { - As } \\
\text { - Hg } \\
\\
\text { INADVERTANT } \\
\text { CONTAMINATION } \\
\\
\end{array}$ & $\begin{array}{l}\text { (b) ANALYSIS OF } \\
\text { SAMPLE ON } \\
\text { RECEPIT. } \\
\text { (c) EXAMINATION } \\
\text { OF PACKAGES } \\
\text { FOR DAMAGE. }\end{array}$ & $\begin{array}{l} \\
\text { TEMPERATURE, } \\
\text { HUMIDIT, PERIOD } \\
\text { OF STORAGE }\end{array}$ & $\begin{array}{l}\text { (b) SAMPLING } \\
\text { FROM EACH } \\
\text { BATCH AND } \\
\text { TESTING. } \\
\text { VISUAL } \\
\text { EXAMINATION OF } \\
\text { ALL PACKAGES } \\
\text { FOR DAMAGES. } \\
\text { REJECT } \\
\text { DAMAGED } \\
\text { PACKAGES. } \\
\text { INSPECTION OF } \\
\text { STORAGE } \\
\text { CONDITIONS AND } \\
\text { QUANTITES } \\
\text { STORED }\end{array}$ & $\begin{array}{l}\text { EVERY BATCH } \\
\text { OF SUPPLY } \\
\qquad .\end{array}$ & $\begin{array}{c}\text { PRIMA LTD. } \\
\text { (APPROPRIATE } \\
\text { DEPT) } \\
\text { PRIMA LTD. } \\
\text { (APPROPRIATE } \\
\text { DEPT) }\end{array}$ & $\begin{array}{l}\text { SAMPLING } \\
\text { REPORTS AND } \\
\text { TEST REPORTS. } \\
\\
\text { INSPECTION } \\
\text { REPORT ON } \\
\text { EACH BATCH }\end{array}$ \\
\hline
\end{tabular}




\begin{tabular}{|c|c|c|c|c|c|c|c|}
\hline $\begin{array}{l}\text { PROCESS } \\
\text { STEPI } \\
\text { CONTROL } \\
\text { POINT }\end{array}$ & $\begin{array}{l}\text { SAFETYIQUALITY } \\
\text { ASPECT (ISSUE) } \\
\text { ADDRESSED) }\end{array}$ & $\begin{array}{l}\text { CONTROU } \\
\text { PREVENTIVE } \\
\text { MEASURE }\end{array}$ & CONTROL LIMIT & $\begin{array}{l}\text { MONITORING } \\
\text { PROCEDURE }\end{array}$ & FREQUENCY & RESPONSIBILITY & RECORDS \\
\hline $\begin{array}{l}\text { PRE-MIXING } \\
\text { (RIBBON } \\
\text { BLENDER) } \\
\text { (CP2) }\end{array}$ & $\begin{array}{l}\text { QUALITY OF } \\
\text { FORTIFICANT AND } \\
\text { FLOUR. }\end{array}$ & $\begin{array}{l}\text { (b) MIXING IN } \\
\text { ACCORDANCE } \\
\text { WITH } \\
\text { CONDITIONS } \\
\text { LAID DOWN }\end{array}$ & $\begin{array}{l}\text { 1:1 Mix } \\
40 \mathrm{~kg} \text { fortificant } \\
40 \mathrm{~kg} \text { flour } \\
\\
3-4 \text { Minutes } \\
\text { MIXING IN } \\
\text { THE RIBBON } \\
\text { BLENDER }\end{array}$ & \begin{tabular}{|l} 
RECORD \\
QUANTITIES \\
ADDED FOR \\
EACH MIX, WITH \\
IDENTIFICATION \\
NUMBER FOR \\
EACH BATCH \\
OPERATOR \\
ENSURES THAT \\
MIXING TIME AND \\
OTHERCONDITIONS \\
ARE WITHIN \\
THESE LIMITS. \\
\end{tabular} & $\begin{array}{l}\text { EACH BATCH } \\
\text { OF PRE-MIX }\end{array}$ & $\begin{array}{l}\text { OPERATOR } \\
\text { RESPONSRLE } \\
\text { FORMIXING }\end{array}$ & $\begin{array}{l}\text { DAILY RECORDS } \\
\text { COVERING } \\
\text { PRE-MIX } \\
\text { BATCHES AND } \\
\text { QUANTITIES } \\
\text { USED. } \\
\\
\text { MIXING TIME } \\
\text { ON EACH } \\
\text { BATCH }\end{array}$ \\
\hline $\begin{array}{l}\text { STORAGE OF } \\
\text { PRE-MIX } \\
\text { (UNTIL USE) } \\
\text { (CP3) }\end{array}$ & $\begin{array}{l}\text { IDENTITY OF PREMDX } \\
\text { PACKAGES }\end{array}$ & $\begin{array}{l}\text { (a) PROPER } \\
\text { LABELLING OF } \\
\text { PRE-MIX } \\
\text { PACKAGES }\end{array}$ & & $\begin{array}{l}\text { EACH PRE-MIX } \\
\text { PACKAGE LABELLED } \\
\text { WITH QUANTITY } \\
\text { OF PRE-MIX, DATE } \\
\text { ANDBATCH IDENTI- } \\
\text { FICATION NUMBER, } \\
\text { AT THE MIXING } \\
\text { POINT. }\end{array}$ & $\begin{array}{l}\text { EACH BATCH } \\
\text { OF PRE-MIX } \\
\end{array}$ & $\begin{array}{l}\text { OPERATOR } \\
\text { RESPONSBLE } \\
\text { FOR MIXING }\end{array}$ & $\begin{array}{l}\text { QUANTTTY AND } \\
\text { NUMBER OF } \\
\text { PACKAGES } \\
\text { PRODUCED } \\
\text { WITH DATES. }\end{array}$ \\
\hline & $\begin{array}{l}\text { DETERIORATION } \\
\text { DURING STORAGE }\end{array}$ & $\begin{array}{l}\text { (b) STORAGE } \\
\text { UNTIL USE } \\
\text { UNDER } \\
\text { APPROPRIATE } \\
\text { CONDITIONS }\end{array}$ & \begin{tabular}{|l} 
TEMPERATURE, \\
HUMIDITY,PERIOD \\
OF STORAGE
\end{tabular} & $\begin{array}{l}\text { CONDITIONS IN } \\
\text { STORES } \\
\text { CONTROLLED. } \\
\text { FIRST-IN-FIRST- } \\
\text { OUT SYSTEM. }\end{array}$ & CONTINUOUS & $\begin{array}{l}\text { PRODUCTION } \\
\text { DEPT. } \\
\text { (SUPERVISOR) }\end{array}$ & $\begin{array}{l}\text { STORAGE } \\
\text { QUANIITY IN/ } \\
\text { OUT WTIH } \\
\text { DATES }\end{array}$ \\
\hline
\end{tabular}




\begin{tabular}{|c|c|c|c|c|c|c|c|}
\hline $\begin{array}{l}\text { PROCESS } \\
\text { STERI } \\
\text { CONTROL } \\
\text { POINT }\end{array}$ & $\begin{array}{l}\text { SAFETY/QUALITY } \\
\text { ASPECT (ISSUIG) } \\
\text { ADDRESSED) }\end{array}$ & $\begin{array}{l}\text { CONTROY } \\
\text { PREVENITVE } \\
\text { MEASURE }\end{array}$ & CONTROL UIMTT & $\begin{array}{l}\text { MONITORING } \\
\text { PROCEDURE }\end{array}$ & FREQUENCY & RESPONSIBILITY & RECORDS \\
\hline $\begin{array}{l}\text { ADDMIIONOF } \\
\text { PRE-MIX TO } \\
\text { FLOUR } \\
\text { (FEEDER) } \\
\text { (CP4) }\end{array}$ & $\begin{array}{l}\text { RATEOF ADDITION } \\
\text { OF PRE-MIX }\end{array}$ & $\begin{array}{l}\text { (a) EACH } \\
\text { PRE-MIX } \\
\text { PACKAGE } \\
\text { IDENTIFIED BY } \\
\text { TAGS OR LABELS. } \\
\\
\text { (b) QUANTITYOF } \\
\text { PRE-MIX ADDED } \\
\text { TO EACH LINE } \\
\text { HOPPER WITH } \\
\text { TIMES OF } \\
\text { ADDITON. } \\
\\
\text { (C) REGULAR } \\
\text { VSUALCHECKS } \\
\text { ON THE FEEDER } \\
\\
\text { (d) DAIYYCHECK } \\
\text { ON RECORDS ON } \\
\text { EACHLINE } \\
\text {-AMOUNT OF } \\
\text { PRE-MIX USEDVS. } \\
\text { FOUR PRODUC- } \\
\text { TONON }\end{array}$ & $\begin{array}{l} \\
\\
125 \text { - 135g OF } \\
\text { PRE-MIX PER 1M } \\
\text { TON OF FLOUR } \\
\text { PRODUCED TO } \\
\text { GIVE 66mg/kg OF } \\
\text { IRON IN } \\
\text { FLOUR) } \\
\text { CHECK AND VERIFY } \\
\text { THAT METER } \\
\text { READINGS ARE } \\
\text { WITHIN SPECIFIED } \\
\text { LIMIT. } \\
\text { THE PRE-MIX USED } \\
\text { AT THE RATE OF } \\
\text { 130 } 5 \text { P PER 1MT } \\
\text { OF FLOUR } \\
\text { PRODUCED }\end{array}$ & \begin{tabular}{|l} 
CHECK AND \\
VERIF THE \\
LABEL AND \\
DETERMINE THAT \\
PRE-MIX IS \\
SUITABLE FOR \\
ADDITION \\
\\
QUANTITY OF \\
PRE-MIX ADDED \\
TO HOPPER WITH \\
TIME OF \\
ADDITON TO BE \\
RECORDED. \\
\\
VISUAL CHECKS TO \\
VERIFY THAT THE \\
PRE-MIX IS BEING \\
USED AT A \\
CONSTANT RATE. \\
RECORDS PER 8-10 \\
HOURS (1 SHIFT) \\
SHOULD BE \\
CHECKED
\end{tabular} & \begin{tabular}{|l|} 
EACH PRE-MIX \\
PACKAGE \\
ADDED TO \\
HOPPER OF THE \\
FEEDER IN EACH \\
LINE (5 LINES) \\
TO BE KEPT \\
SEPARATELY. \\
EACH PRE-MIX \\
PACKAGE \\
ADDED.
\end{tabular} & $\begin{array}{l}\text { LINE OPERATOR } \\
\text { LINE OPERATOR } \\
\text { INE OPERATOR } \\
. \\
\text { PRODUCTION } \\
\text { EXECUTIVE }\end{array}$ & $\begin{array}{l}\text { IDENTIFICATION } \\
\text { OF PRE-MIX } \\
\text { PACKAGE, } \\
\text { QUANTITY AND } \\
\text { TIME OF } \\
\text { ADDITON TO } \\
\text { BE RECORDED. } \\
\text { AS ABOVE } \\
\\
\\
\\
\text { RELEVANT } \\
\text { METER } \\
\text { READING AND } \\
\text { TIME OF } \\
\text { RECORDING. } \\
\text { TALIED DAIY } \\
\text { RECORDS } \\
\text { SHOWING } \\
\text { PRE-MIX } \\
\text { QUANITY AND } \\
\text { FLOUR PRODUCED } \\
\text { FOR THE SAME } \\
\text { PERIOD }\end{array}$ \\
\hline
\end{tabular}




\begin{tabular}{|c|c|c|c|c|c|c|c|}
\hline $\begin{array}{l}\text { PROCESS } \\
\text { STEPI } \\
\text { CONIROL } \\
\text { POINT }\end{array}$ & $\begin{array}{l}\text { SAFETY/QUALITY } \\
\text { ASPECT (ISSUE) } \\
\text { ADDRESSED) }\end{array}$ & $\begin{array}{l}\text { CONTROU } \\
\text { PREVENTIVE } \\
\text { MEASURE }\end{array}$ & CONTROL LIMIT & $\begin{array}{l}\text { MONITORING } \\
\text { PROCEDURE }\end{array}$ & FREQUENCY & RESPONSIBILITY & RECORDS \\
\hline $\begin{array}{l}\text { BAGGING } \\
\text { OF IRON } \\
\text { FORTIFIED } \\
\text { FLOUR } \\
\text { (CP5) }\end{array}$ & $\begin{array}{l}\text { IRON CONTENT } \\
\text { IN FINISHED } \\
\text { PRODUCTS. }\end{array}$ & $\begin{array}{l}\text { (a) ANLYSIS OF } \\
\text { SAMPLES FOR } \\
\text { IRON CONTENT }\end{array}$ & $\begin{array}{l}\text { 75mg/kg OF } \\
\text { IRON INEINAL } \\
\text { PRODUCT. } \\
\pm 10 \mathrm{mg} / \mathrm{kg} \\
\text { TOLERANCE } \\
\text { ALLOWED }\end{array}$ & $\begin{array}{l}\text { COMPOSITE } \\
\text { SAMPLE TO BE } \\
\text { COLLECTED JUST } \\
\text { BEFORE BAGGING } \\
\text { POINT }\end{array}$ & $\begin{array}{l}\text { ONE } \\
\text { SAMPLE } \\
\text { ANALYSIS } \\
\text { DAILY. }\end{array}$ & $\begin{array}{l}\text { QUALITY } \\
\text { CONTROL } \\
\text { DEPT. }\end{array}$ & $\begin{array}{l}\text { DAILY TEST } \\
\text { RECORDS TO BE } \\
\text { MAINTAINED. }\end{array}$ \\
\hline $\begin{array}{l}\text { DELIVERY } \\
\text { AND ISSUE } \\
\text { OF IRON } \\
\text { FORTIFIED } \\
\text { FLOUR BY } \\
\text { FOOD } \\
\text { DEPARTMENT } \\
\\
\text { (CP6) }\end{array}$ & $\begin{array}{l}\text { IRON CONTENT } \\
\text { IN FINISHED } \\
\text { PRODUCTS. }\end{array}$ & $\begin{array}{l}\text { ANLYSIS OF } \\
\text { SAMPLES FOR } \\
\text { IRON CONTENT }\end{array}$ & $\begin{array}{l}\text { 75mg/kg OF IRON } \\
\text { IN FINAL } \\
\text { PRODUCT. } \\
\pm 10 \mathrm{mg} / \mathrm{kg} \\
\text { TOLERANCE } \\
\text { ALLOWED }\end{array}$ & $\begin{array}{l}\text { (a) COMPOSITE } \\
\text { SAMPLE* } \\
\text { COLLETED FROM } \\
\text { FOODDEPT.STORE } \\
\text { ATTHE } \\
\text { FACTORY SITE. } \\
\\
\\
\text { (b) SAMPLES* } \\
\text { COLLECTED FROM } \\
\text { FOODDEPT.STORES } \\
\text { IN DISTRICTS. } \\
\text { * SAMPLING - AS } \\
\text { IN SLS } 144\end{array}$ & $\begin{array}{l}\text { ONE } \\
\text { SAMPLE PER } \\
\text { MONTH } \\
\text { ONE } \\
\text { SAMPLE PER } \\
\text { MONTH }\end{array}$ & $\begin{array}{l}\text { SAMPLING BY } \\
\text { ASST. DIRECTOR/ } \\
\text { QC OFFICER } \\
\text { FOOD DEPT. AT } \\
\text { FACTORY SITE. } \\
\text { TESTS } \\
\text { ARRANGED BY } \\
\text { QC UNIT FOOD } \\
\text { DEPT. COLOMBO. } \\
\\
\text { OC UNIT } \\
\text { FOOD DEPT. } \\
\text { COLOMBO. }\end{array}$ & $\begin{array}{l} \\
\text { TEST RECORDS } \\
\text { TO BE } \\
\text { MAITAININED } \\
\text { BYQC UNIT } \\
\text { FOOD DEPT. } \\
\text { COLOMBO. } \\
\\
\\
\text { (ANY DEVIA- } \\
\text { TLONSFROM } \\
\text { LIMITS TO BE } \\
\text { REPORTED } \\
\text { IMMEDIATELY) }\end{array}$ \\
\hline
\end{tabular}




\section{Conclusion}

Iron fortification of wheat flour has been considered favourably by the GOSL as a means to combat iron deficiency in the Sri Lankan population. Adherence to general principles for addition of nutrients to food and related good manufacturing practices is essential to assure safety and derive full benefits from such a fortification programme. Assuring safety and quality of such fortified foods is the responsibility of all stakeholders and interested groups involved in the process. A properly designed QA system should be installed and implemented with the participation of all concerned to assure safety and quality of the fortified food.

The quality system recommended in this report could be implemented by effectively integrating with the present $Q C$ system. Installing and implementing the QA system will be the responsibility of the mill management. However, it would be the responsibility of the GOSL and the relevant regulatory authorities to see that adequate and effective systems are installed and practised to assure safety and quality of products. Sufficent financial resources should be made available by the GOSL for the implementation of this QA programme in the event a positive decision is made to implement the programmne for fortification of wheat flour with iron.

\section{References}

1. Wikramanayake TW. Combating Iron Deficiency. Editorial Introduction. Ceylon Journal of Medical Science 1996; 39: 1-8.

2. Mudalige R, Nestel P. Prevalence of anaemia in Sri Lanka. Ceylon Journal of Medical Science 1996; 39: 9-16.

3. Piyasena $C$, Mudalige R, Nestel P. Wheat consumption patterns in Sri Lanka. Ceylon Journal of Medical Science 1996; 39: 17-22.

4. Gooneratne J, Mudalige R, Nestel P, Purvis G. Product evaluation using iron-fortified wheat flour. Ceylon Journal of Medical Science 1996; 39: 23-34. 